\title{
Future Prospects and Health Benefits of Functional Ingredients from Marine Bio-resources: A review
}

\author{
Kalpa W. Samarakoon ${ }^{1, a}$, Don Anushka Sandaruwan Elvitigala ${ }^{1}$, H.H.Chaminda Lakmal ${ }^{1}$, Young-Mog Kim ${ }^{2 *}$ \\ and You-Jin Jeon ${ }^{1 *}$ \\ ${ }^{1}$ Department of Marine Life Science, Jeju National University, Jeju 690-756, Korea \\ ${ }^{2}$ Department of Food Science and Technology, Pukyong National University, Busan 608-737, Korea \\ aPresent address: Herbal Technology Section, Industrial Technology Institute (CISIR), Colombo 7, Sri Lanka
}

\begin{abstract}
The marine ecosystem represents a vast and dynamic array of bio-resources attributed with its huge diversity and considered as potential untapped reservoirs for the development of functional foods for future health markets. Basically, marine microorganisms, sponges, algae, invertebrates such as crustaceans and mollusks along with marine fish species can be considered as marine bio-resources, which can be utilized to obtain different health benefits for humans, directly or after processing. Most of the bio-molecular components, such as lipids and proteins from these marine bio-resources, which can be extracted in large scale using the modern and advanced biotechnological approaches, are suitable drug candidates for the pharmaceutical industry as well as functional food ingredients for the food industry. Moreover, the furtherance of high throughput molecular biological techniques has already been incorporated with identification, mining and extraction of molecular components from marine bio-resources. In this review, potential marine bio-resources with respect to their extractable bio-molecules were described in details, while explaining the present and prospective methods of identification and extraction, which are integrated with advanced techniques in modern biotechnology. In addition, this provides an overview of future trends in marine biotechnology.
\end{abstract}

Key words: Marine Bio-resources, Biotechnology advances, Proteins, Molecular biology

\section{Introduction}

The life of the earth has been originated from the ocean. The oldest fossil evidences showed that rise of environment oxygen by oxygen producing eukaryotes and cyanobacteria was appeared over 2.45-2.32 billion years ago (Rasmssen et al., 2008). Afterwards, many of organisms or evolutionary forms have been evolved from that primitive age to contemporary state by having extraordinary structural variations (Cracraft and Donoghue, 2005). On the other hand, abiotic factors such as light intensity, temperature, nutrients and salinity levels make much influence for their biological functions. Furthermore, extreme fluctuations of climate accord- ing to seasons have been given a major outbreak through the variations and to be survived in the competitive environmental conditions (Plaza et al., 2008). However, the evolution of the diverging forms with respect to their biochemical and morphological traits are still being taking place with the adaptive establishments in the ocean. In that case, marine bacteria, fungi, sponges, algae (macro or micro), crustaceans, mollusks, fish and small vertebrates have been identified as the major classes that comprise the diversity of marine biomass. As the consequences of this diversity, biochemically and ecologically significant differences have brought with the vast marine
(C) 2014 The Korean Society of Fisheries and Aquatic Science This is an Open Access article distributed under the terms of the Creative Commons Attribution Non-Commercial Licens (http://creativecommons. org/licenses/by-nc/3.0/) which permits unrestricted non-commercial use, distribution, and reproduction in any medium, provided the original work is properly cited.
Received 23 April 2014; Revised 19 June 2014

Accepted 23 June 2014

*Corresponding Author

E-mail: youjinj@jejunu.ac.kr (You-Jin Jeon) ymkim@pknu.ac.kr (Young-Mog Kim) 
biomasses and have been associated with a broad spectrum of secondary metabolites. However, the significant gains are continually being improved due to the exploration of novel secondary metabolites from the ocean. Therefore, it is logical to consider that mining of natural products and functional ingredients from the marine biomasses would be a productive commencement in the view point of pharmacology (Imhoff et al., 2011).

There has been existed long tradition of consuming seafood as a delicacy along with the human diet for many centuries, (Kim and Wijesekara, 2010). Ancient people in many parts of the world would have believed that the steady enhancement of life expectancy and long term health effects, quality and care could be rendered by the marine functional ingredients. Consumption of seafood is considered as a preventive strategy against lifestyle diseases and fruitful solution for the prospective health challenges. Moreover, substantial scientific evidences have been shown that direct consumption of seafood or food supplements may contribute for the health promoting effect (Cencic and Chingwaru, 2010). A sufficient intake of seafood nutrients has been linked for preventing chronic heart disease and relieving from many more health problems. In addition, largely derived human clinical studies have encompassed the vast array of health benefits from marine foods $(\mathrm{Hu}$ et al., 2002; Marchioli, 2003; Lavie, 2009). Furthermore, seafood commodities including fish, shellfish and seaweeds are commonly used for delicacies in many parts of the world and highly demanded natural comestibles in the global food market. This can be well understood by the tremendous diversity of the seafood and their nutritional characteristics including poly unsaturated fatty acids (PUFA) such as eicosapentaenoic acids (EPA) and docosahexaenoic acids (DHA) (Lichtenstein et al., 2006; Elvevoll et al., 2008) as well as proteins (Friedman, 1996; Kitts and Weiler, 2003; Samarakoon and Jeon 2012), bioactive peptides (Kawasaki et al., 2000; Kim and Wijesekara, 2010), free amino acids (Elvevoll et al., 2008; Petrosian and Haroutounian, 2009), enzymes (Fernandes, 2010), vitamins (Holick, 2009), minerals (Andersson et al., 2010; Zimmermann, 2010) and other functional ingredients (Kanazawa, 2001; Heo et al., 2005; Wu et al., 2009) which are proven to play significant beneficial roles in human health (Lavigne et al., 2001; Boukortt et al., 2004; Cohen et al, 2005; Elvevoll et al., 2008; Undeland et al., 2009).

The exploration of marine bio-resources is an indefinite challenge for bio-mining researchers. However, the immersing diversity of marine environment has revealed that the untapped resources are having broad probe to meet the curiosity of the future scientific community. Therefore, this endeavor leads to overview the recent biotechnological aspects on valuable health products, mainly marine proteins and lipids from marine bio-resources through the future prospects, with respect to their increasing sustainability. Hence, this biotechnological and pharmacological scenario will be emphasized due to increasing demands on the marine bio-resources, in order to strengthen the development of marine functional foods, nutraceuticals and associated medicinal benefits.

\section{Possible applications on extractions and isolation of functional ingredients}

Marine functional materials can elicit positive health benefits with long term efficacy. Therefore, these materials are believed to be implemented a novel strategy for the functional foods in the marine biotechnology. Over the many years, a vast array of structural and biochemical diversity in terms of the various marine organisms might have targeted for the screening projects (Plaza et al., 2008). Effective ways of screening, bio-mining and advancing of bioactive natural products using appropriate techniques, in order to commercialize the respective products are highly concerned matters in the modern field of marine biotechnology. Furthermore, the development of functional materials for the functional foods and identification of possible extraction methods are performed with the respective parameters such as heat resistance, solubility, molecular weights. In this regard, two possible extraction methods are described preliminary, designated as enzymatic hydrolysation and organic solvent extraction (Kim and Wijesekara, 2010). Even though numerous extraction methods are currently employed, only few of them are suitable for industrial scale. In addition, solid-liquid extraction (SLE), liquid-liquid extraction (LLE) and soxhlet extraction (SE) techniques are characterized as less economical strategies. Furthermore, high volumes of solvents should be used with long time proceedings in those procedures, which may in turn lead to remain toxic residues with the final extracts. Therefore, sophisticated green methodologies are described to increase the yield, purity and reproducibility of the target compounds (Wang et al., 2010). However, enzymatic hydrolysation can be preferred to isolate proteins, lipids and their bioactive constituents, with the safe, time and cost effective way from the heterogeneous sources. Despite the fact, chemical extractions (using organic solvents) are also applicable as a popular method to isolate bio-functional materials in the traditional way. For example, recovering of PUFA as free fatty acids from the marine oil followed by saponification, isolation, purification and crystallization techniques were performed depending on the solubility of the particular chemical and available distillation methods (Shahidi and Wanasundara, 1998). However, purification of proteins, mainly enzymes, peptides and free amino acids can be purified with the ultra-membrane filtration (UF), gel or size exclusive column chromatography and couple with the high performance liquid chromatography (HPLC). The mass determination and structure elucidations may further subjected using liquid chromatography-mass spectrophotometer (LCMS) or mass-mass spectrophotometer (MS-MS) along with the nuclear magnetic resonance spectrophotometer (NMR) (Chabeaud et al., 2009). 


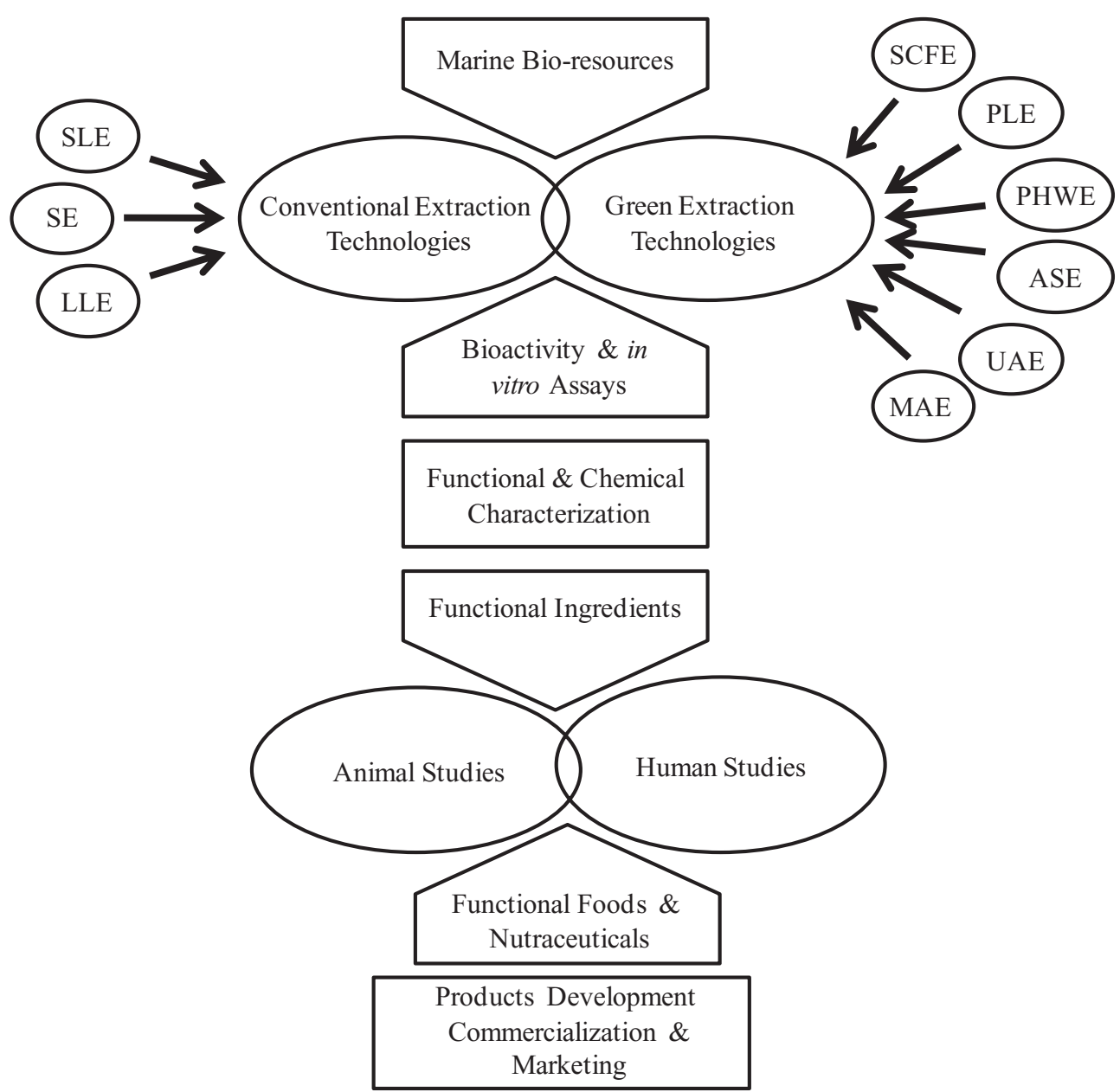

Fig. 1. Flow chart of the possible exploration and development of the functional ingredients from marine bio-resources through the conventional and green extraction technologies for future pharma-nutra applications.

However, the commercialization of proteins and lipids would become an interesting view for the functional and medicinal industries as new chemical-entities for leadcompounds or innovative drugs from marine bio-resources. Therefore, in recent years, the pharmaceutical firms have a look towards the investigation and utilization of new isolation methodologies under optimized conditions, which would become efficient with respect to the time consumption and cost in industrial scale, rather than the laboratory-scale. The technological advances in industrial-scale (i.e. combining conventional membrane filtration with electrophoresis on separating highly charged bioactive peptides) might render fast separation rather than chromatography (Bargeman et al., 2002). In addition, the highest degree of technologies such as supercritical fluid extraction (SCFE), pressurized liquid extraction (PLE), pressurized hot water extraction (PHWE), accelerated solvent extraction (ASE) as well as ultrasound-assisted (UAE) and microwave-assisted (MAE) extraction have been used in recent marine bio-resource extractions and functional food formulations (Herrero et al., 2006a). Moreover, bioactivity guided fractionations lead to determine the fastest and accurate way to reach the last step of separation procedures. However, the sequential chromatographic steps involve further purification and characterization of innovative secondary metabolites from the marine natural sources. Moreover, the purified functional materials can be used to scale up the activities, testing the efficacy of in vitro assays, analytical techniques to quantify minor components and animal or human clinical studies may further needed to establish the health prospects before the development and commercialization (Fig. 1).

\section{Pharmacological and nutritional view of marine proteins and lipids}

The very long evolutional period of marine life than the terrestrial life has generated a massive biodiversity throughout the species at genomic level. Thus marine bio-resources are showing a broad spectrum of biomedical constituents. 
Therefore, it is believed that the vast number of reports have encountered the significances of medicinal effects from marine bio-resources (Dufosse et al.,2005; Ward and Singh, 2005; Zengler et al., 2005; Chang et al., 2008; Rodriguez et al., 2010; Ivanchina et al., 2011; Senni et al., 2011; Sperstad et al., 2011). Furthermore, various interests over the pharmacological and nutraceutical effects of the proteins including enzymes, peptides and free amino acids, and also lipids including saturated and unsaturated fatty acids from marine organisms will be discussed in the next part of this review.

\section{Marine proteins and protein-derived constituents}

Proteins, bioactive peptides and free amino acids derived from marine sources have gained a much attention due to promising health benefits (Samarakoon and Jeon, 2012). Basically most of the marine bio-resources are comprised of high content of proteins than the other functional materials. Interestingly, marine microalgae, muscle tissues of fish, shellfish and other invertebrates showed the range of $15-65 \%(\mathrm{w} / \mathrm{w})$ proteins. In addition, marine fish and shellfish waste along with processing by-products are also considered to be consisted with high quality and quantities of proteins [10-23\% $(\mathrm{w} / \mathrm{w})]$. These sources are targeted as a potential source for mining of active components (Kim and Mendis, 2006; Harnedy and Fitzgerald, 2012). In fact, extractions of these proteins or protein-derived constituents from different sources have been extensively studied (Rutherfurd and Moughan, 2005). Usual extraction protocols of those proteins from organisms are initiated by the disruption of cells of the source and releasing proteins (Patil et al., 2008; Ko et al., 2011; Lee et al., 2011). However, the bioactivity of the proteins may not directly correlate with the intact form of parent proteins.

Free forms of amino acids are also used in high levels of production of food supplements, energy formulations and nutraceuticals in the infant and adult food industries (Stapletonet al., 1997). Taurine and creatine are two main amino acids used commonly in those industries (Petrosian et al., 2009). In terms of the bio-functionalities of the taurine, it showed very high activity and found in most of the organisms as dominant free form. Furthermore these authors have reported that the both amine and sulphonic subunits of taurine can undergo ionization and involve in biological and physiological activities by their dissociation components. Moreover, they were known to be involved in antioxidative reactions (Métayer et al., 2008) immune stimulations (Redmond et al., 1998) homeostasis (Takahashi et al., 1997) cell membrane stabilizations (Han et al., 2000) anti-inflammatory (Chiarla and Giovannini, 2004) developmental regulation of renal functions (Han et al., 2000) endocrine and metabolic effects (Rose, 1996) in humans. In fact, raw flesh fish, raw clams and raw mussels are also known to contain high taurine levels, among the marine organisms (Stapleton et al., 1997). On the other hand, creatine is also being considered as an important free or phosphorylated form of amino acid that furnishes positive physiological effects for humans. Moreover, skeletal muscle regeneration, contraction by performing on cardial muscles (Gordon et al., 1995) and fat-free mass promotion (Sullivan et al., 2000) has also been encountered by creatine level in human body.

Importantly, bioactive peptides showed much significant roles in the pharma-nutraceutical applications (Shahidi and Zhong, 2008). Marine food sources have exerted many of bioactive peptides and the peptide sequences may short and consisted of 3-20 amino acid residues. Therefore, isolation and purification of bioactive peptides could be described by facilitating upon the proteolytic enzyme hydrolysation and follow the activity guided fractionations (Sheih et al., 2009). Moreover, the composition and number of amino acid residues of the isolated peptides exert their bioactivity (Pihlanto-Leppala, 2001). Hence, the identified bioactivities have given a wide range of physiological applications.

Most of these bioactive peptides have been obtained from enzymatic hydrolysation of marine organisms including algae, fish, shellfish (Suetsuna and Chen, 2001; Je et al., 2008) fermented marine food sources processed by microorganisms (Je et al., 2005; Je et al., 2008) and marine processing byproducts (Kim et al., 2000; Kim et al., 2001). These peptides demonstrated the overall effect of the human health claims and the knowledge of the diet make the awareness of functional foods and nutraceuticals (Erdmannet et al., 2008; Elias et al., 2008; Samaranayaka and Li-Chan, 2011). Interestingly, bioactive peptides and amino acids may act as alternative molecules to small molecular drugs. Moreover, those have shown a great advantage over the conventional drugs with high bioavailability and bio-specificity to the targets. The desirable properties of these molecules, such as low toxicity, structural diversity and least or no accumulations in the body tissues have rendered the interest of many scientists to use for the therapeutic purposes. Furthermore, during the gastrointestinal digestion, bioactive peptides may not be broken down and can provoke the positive health effects that have confirmed by in vivo studies (Ko et al., 2012). Anti-ACE and anti-obesity studies have linked with the active peptides and mediated through stimulation of hormones and regulatory satiety. In addition, Quantitative Structure-Activity Relationship (QSAR), that is modeling information, can be used to predict the peptide structures with the ability to cross membrane barriers in the specific target sites (Jimsheena and Gowada, 2010). Furthermore, the improvement of the structures, stabilities and binding capacities of the bioactive peptides with the respective binding sites of human model systems incorporation with synthetic peptides can be strengthen the knowledge of peptides.

Enzymes based biotechnologies have been emphasized and released a broad range of functional metabolites from marine bio-resources over the last few years. With the growing interest of industrial applications and development of new extractions protocols, the exploration of new enzymes or enzyme sources have given a new era for the future biotechnology. In 
particular, a high specificity and a very high reactivity even at low concentrations have been facilitated in different enzymes to use in multiple purposes (Gudmundsdottir and Bjarnason, 2008). In this regard, marine organisms have targeted to isolate stable novel enzymes at hyperthermal and extremely acidic conditions even from the coldest habitats of the marine organisms which are being extensively studied (Debashish et al., 2005). Especially enzymatic applications in food processing, diagnostics, molecular biology research, pharmacological and health care as well as environment monitoring applications have been developed (Shahidi and JanakKamil, 2001). Some of the isolated and purified marine enzymes which were biochemically characterized as for future applications were summarized in Table 1.

\section{Marine Lipids}

Marine bio-resources are characteristically comprised of a significant lipid composition which takes a greater attraction for many lipids, including monogalactosyl diacylglycerols (MGDG), digalactosyl diacylglycerols (DGDG), and phosphatidylglycerols (PG). In addition, Bruno et al. (Bruno et al., 2005) have shown that these bio-molecules are attributed with health promotion effects. Over the many years, the extensive studies have documented that the lipid fractions of marine food sources are primarily consisted of poly unsaturated fatty acids (PUFA). This represents omega-3 and omega-6 fatty acids, including eicosapentaenoic (EPA) or docosahexaenoic acids (DHA).

Consumption of seafood is proven to be preventing the life style diseases and giving a long term health claims. It has been noticed and widely accepted that the long chain omega-3 fatty acid molecules help to prevent cardiovascular diseases (Ward and Singh, 2005; Calzolari et al., 2009; Zuliani et al., 2009; Schuchardt et al., 2010; Stengel et al., 2011). In addition, abundant evidences have shown that fish oil, shellfish and seaweed PUFA can reduce the risk of certain cardiovascular diseases (Saremi and Arora, 2009; Marik and Varon, 2009). Furthermore, consumption of fish for one or two times per week may enhance the protective effect against coronary heart diseases; especially reducing the death risk by $36 \%$ and $17 \%$ from total mortality due to high content of DHA and EPA in the diet (Mozaffarian and Rimm, 2006). A noteworthy finding is that intake of EPA and DHA at $250 \mathrm{mg}$ or range from 850 $\sim 4000 \mathrm{mg}$ per day can expected to provide promising health protective effects by primary and secondary prevention levels (Jacobson, 2006). In addition, the intake of a sufficient amount of these functional ingredients also has been associated to relieving effects of some symptoms or medical conditions such as inflammatory diseases (Rosell et al., 2009), physiological conditions (Appleton et al., 2010), diabetes (Patel et al., 2007) and cancers (Szymanski et al., 2010). Basically, Riediger et al. (Riediger et al., 2009) have reported that the development of protective effect was mechanistically being proven by epidemiological studies due to pleiotropic effects including inflammation, platelet aggregation, hypertension and hyperlipidemia.

Very recently marine algae have been demanded as materials for production of oil due to the content of lipids for the potential of biodiesel production (Williams and Laurens, 2010). As reported, the content of lipids exists within the range of $(1-5 \%)$ and (15-50\%) in the dry weight of seaweed and microalgae, respectively (Burtin, 2003; Williams and Laurens, 2010). For example, a marine diatom, Phaeodactylum tricornutum showed $30-45 \%$ of PUFA, accounted for EPA up to 20$40 \%$ of the total fatty acids (Plaza et al., 2009). However, the same significant value has been taken on the fish waste and processing by-products with the prolific lipid sources (Ferraro et al., 2010). For example, fish by-product commodities such as sardine, mackerel, shark, and cod contain more than $30 \%$ of PUFA including essential omega-3 and 6 lipids for commercialization (Chakraborty and Raj, 2007). In particular, salmon head consider as a good source of PUFA as major part of the by-products. However, most of these by-products have marketed by recovering their essential lipids as nutraceutical or food supplements recently (Mondello et al., 2006) (Table 2 ). These evidences suggest that the future biotechnology on functional foods and health products may directly depend upon the marine waste and processing by-products. Thus the understanding of the sustainability of the marine bio-resources might be performed much significant role in future (Bimbo, 2007).

\section{Impact of biotechnological advances on marine bio-resources}

The idea of an implementation of the green chemistry and biotechnology for the isolation of marine bioactive components is to sustain, design and develop in environmental friendly way with focusing on new protocols, methods, procedures and systems. The above mentioned technologies have come up with new trends in the future biotechnology and pharmacology applications, in order to improve health benefits without damage to the bio-resources and marine environment as well. Progress of the biotechnology is currently being served for the exploration of new functional materials from marine life. Thus, this can cure health disorders and consider as a challenge to the upcoming diseases as well. However, recent biotechnological aspects are expected to hold the promising effects against the numerous disciplines, where it can be approached to focus on research tools and strategic importance, such as algae biomass culturing, aquaculture, harnessing biomaterials, bioremediation, bioinformatics, marine genomics, genetic engineering and research infrastructures. These evidences suggest that the importance of the utilization of sustainability of marine bio-resources and protection of marine environment along with its biodiversity for the future benefits of mankind (Baerga-Ortiz, 2009). 


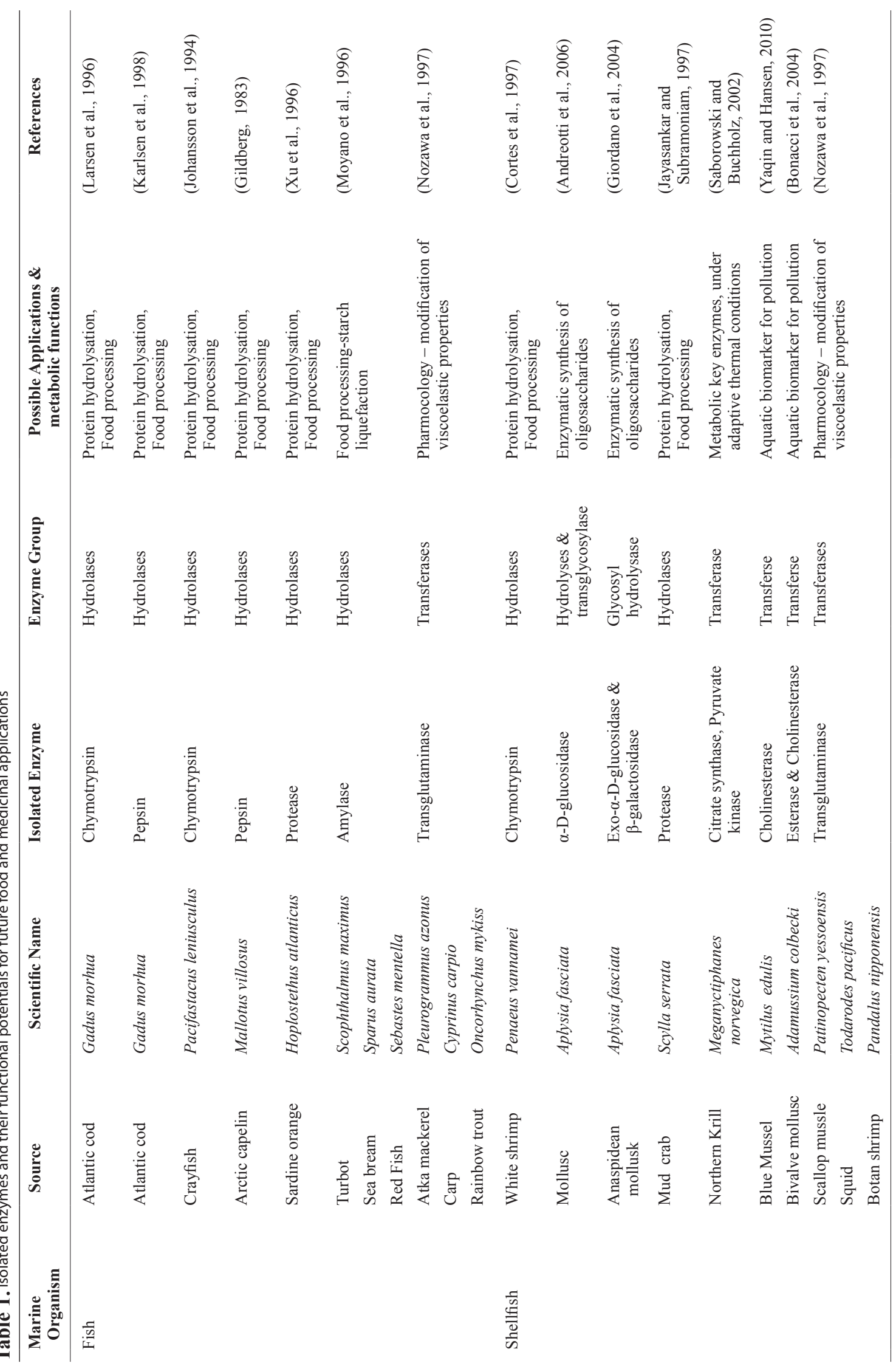




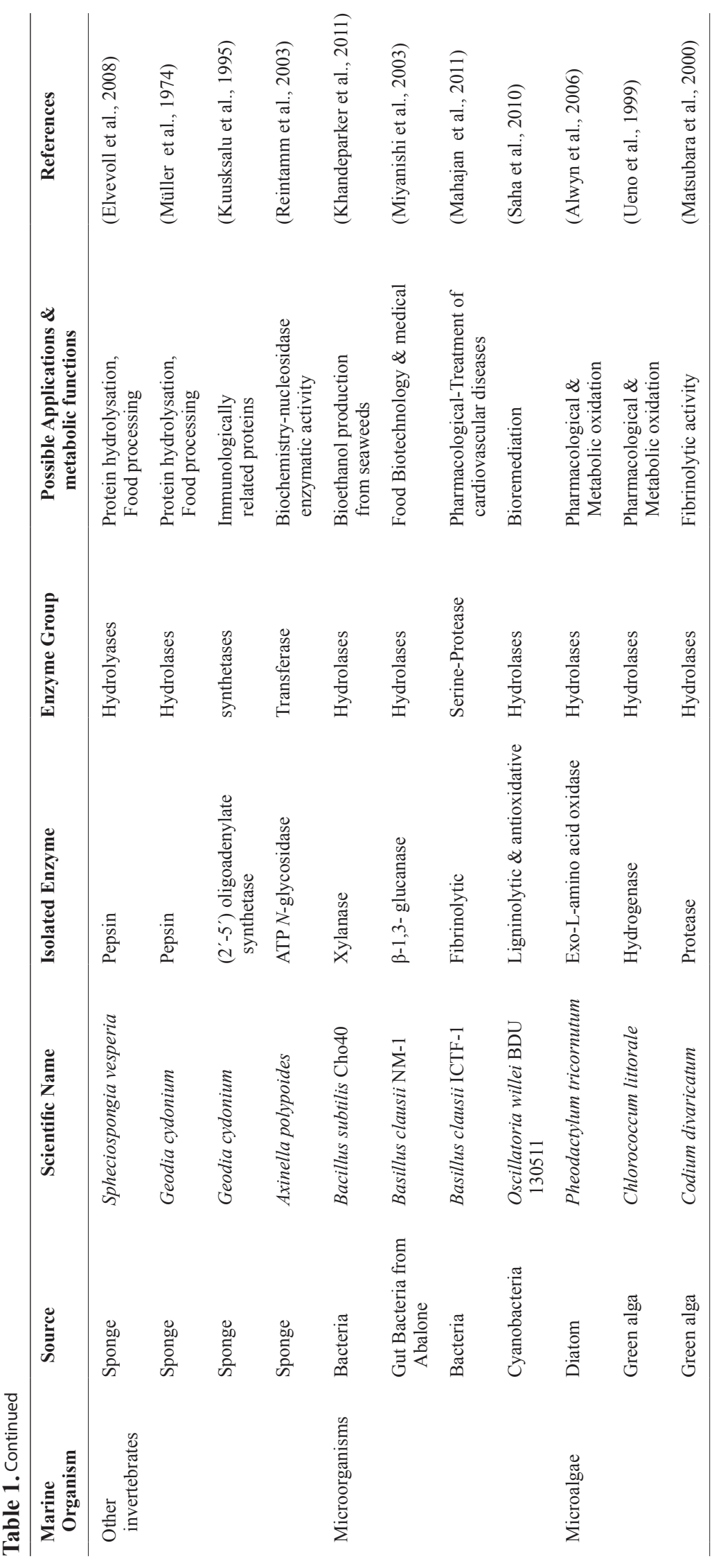




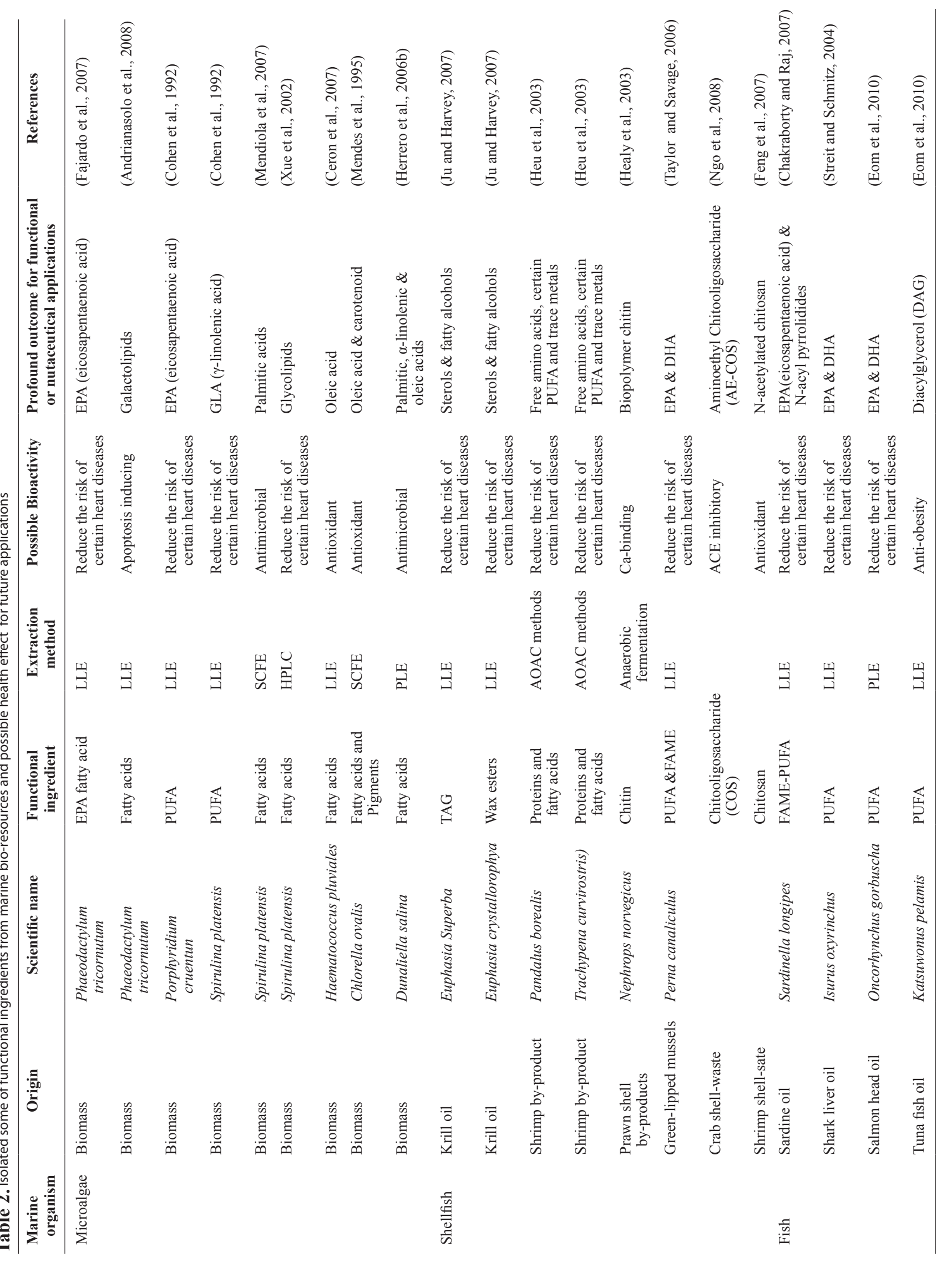




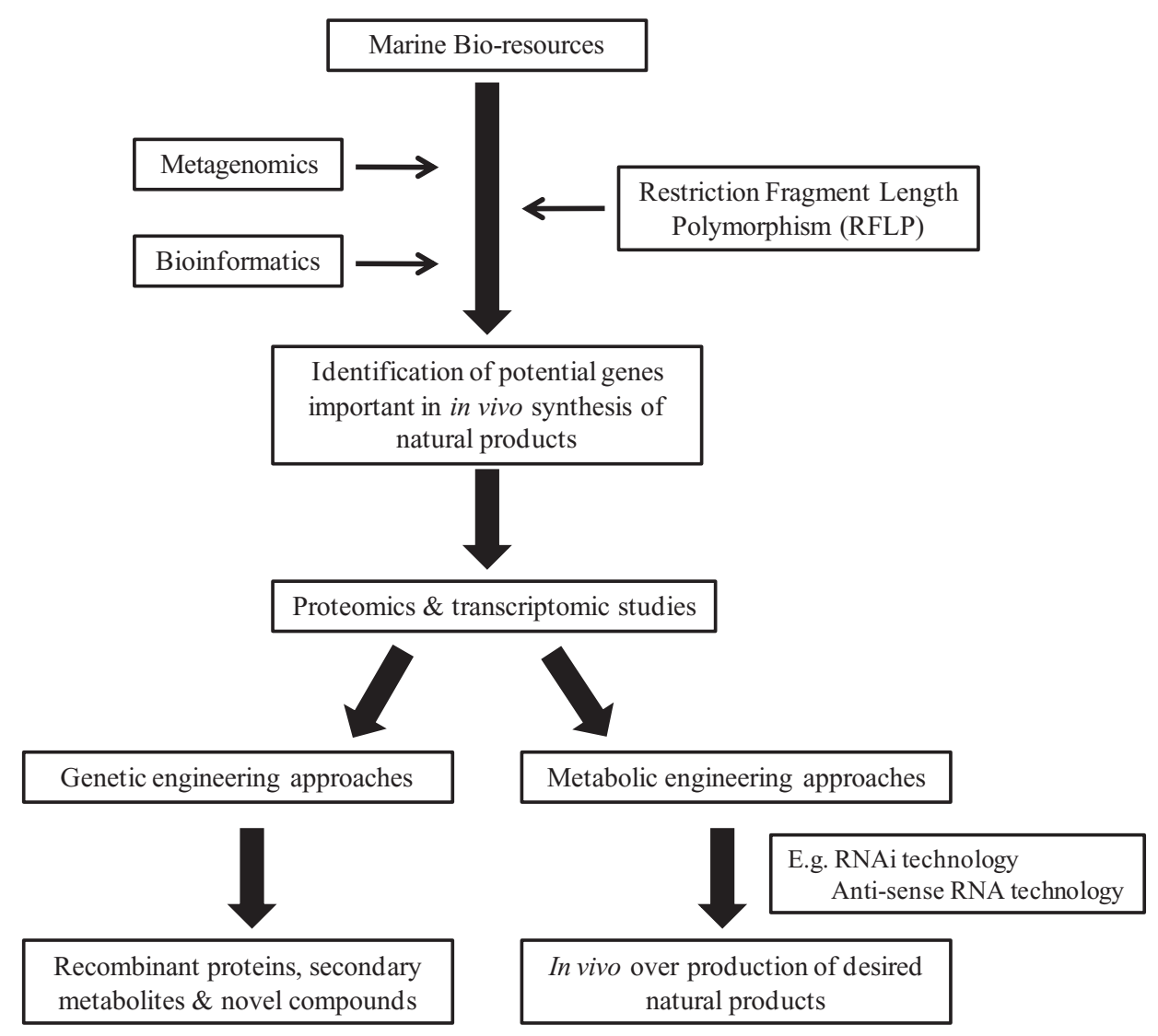

Fig. 2. Flow chart of the investigation and development of functional ingredients via Molecular Biology studies for future biotechnology.

\section{Molecular Biological approaches on investiga- tion and development of marine bio-resources}

Molecular biology is a remarkable field of biology, which is basically dedicated to study on structures and functions of macro molecules like nucleic acids and proteins, with respect to their roles in life processes. However, applications of this promising discipline on marine bio-resources such as microorganisms, algae, invertebrates, vertebrates including economically important fish species have become precious recently. In fact, tremendous collaboration with other related disciplines including marine biology, chemistry and microbiology lead to the sustainable exploration of marine life, mainly for human health and welfare. As described in previous sections, marine eco-system consisted of a huge diversity of organisms and that is a prominent source of wide array of therapeutic agents which can be developed as pharmaceuticals. Novel propagations of molecular biology, including genomics, metagenomics, transcriptomics, proteomics and bioinformatics, along with development of its technologies, such as genetic engineering and bio-activity screening offers a unique opportunity to establish marine natural products as interesting drug candi- dates (Fig. 2).

Most of the microorganisms present in the marine environments are not readily cultivable (Streit and Schmitz, 2004). Therefore culture independent technique is needed for the yielding of natural products from those organisms. This bottleneck can be overcome by metagenomic approaches, which can further maximize the diversity of libraries of marine natural products, through direct accessibility of DNA from marine organisms (Martinez et al., 2005; Zengler et al., 2005). Basically in these genetic strategies, genomic DNA from the interested microorganisms is isolated and digested into large fragments using restriction enzymes. Subsequently, the fragments are cloned into artificial vector systems and sequenced through high throughput sequencing techniques to screen the putative clones for the potent genes or gene clusters encoding the protein components involved in biosynthetic pathways of the corresponding natural products. After detecting particular genes or gene clusters, gene sequence can be analyzed using bioinformatics tools to reveal chemical structure of the desired genes (Zazopoulos et al., 2003; Farnet and Zazopoulos, 2005). This approach may in turn leads to investigate the regulatory mechanisms of the gene expression with respect to the exist- 
ing biosynthetic pathways of natural products or to combine them with genes in other pathways, to synthesize novel compounds (Gust, 2009).

Single cell genomics is an another extension of molecular biology, which can be used as an promising tool to study the entire biochemical potential of single uncultured microbes from complex microbial communities, using a strategy known as multiple displacement amplification (Woyke et al., 2009). Several explorations have been made based on the genomic and metagenomic approaches, including the identification of putative bryostatin polyketide synthase gene cluster from the marine bacterium Candidatus Endobugulase ertula, which encodes crucial constituents in biosynthesis of pharmaceutically potent bioactive compounds, known as bryostatins (Sudek et al., 2007) and characterization of polyketide biosynthesis with respect to the corresponding genes, such as polyketide synthase (PKs) and non-ribosomal peptide synthetase (NRPS), which is responsible for the production of antitumor molecules, from an uncultivated bacterial symbiont of the marine sponge, Theonellaswinhoe (Li and Piel, 2002; Zengler et al., 2005; Teta et al., 2010). In addition, polyketides coding genes were identified in Streptomyces species, convincing the antitumor and antibiotic secretary possibility of marine bacteria as their secondary metabolites (Streit and Schmitz, 2004). Particularly, PKs and NRPS can be used in screening approaches to pre-select new isolates with promising bioactivities for natural product analysis.

Genome sequence tags (GST) are identified genes, involved in natural product biosynthesis, which can be employed as probes to screen clonal libraries, in order to select putative clones for further screening for novel natural product gene clusters in marine organisms. Restriction fragment length polymorphism (RFLP) is a basic molecular biological technique, which is now applied in screening of marine microbial genomic libraries and especially in identification of microbes exhibiting bio-active potential, using PCR amplified fragments of $16 \mathrm{~S}$ and $18 \mathrm{~S}$ rRNA coding genes in marine microbial drug discovery programs (Thakur et al., 2008). Nevertheless, more efforts are in progress to identify and analyze a set of genes present in the genome of marine organisms that encodes a chain of enzymes, further synthesizing bioactive compounds to disclose the hidden potential biosynthetic pathways of marine organisms.

Discovering novel anti-microbial peptides (AMP) can be originated from marine invertebrates; For instance penaedin, crustin and defensing etc, have been facilitated by molecular iological approaches, especially through isolation of cDNA transcripts or express sequence tag (EST) clones which show homology with already characterized AMP sequences, furnishing ease and successful investigations as desirable features (Patrzykat and Douglas, 2003). For an example, Lsstylclin was able to be identified in shrimp Litopenaeus stylirostris using sequence information of its transcripts (Rolland et al., 2010). Using this strategy, around 20 peptide sequences were found to be potentially antimicrobial peptides, including iPAP-A and ci-MAM-A which exhibit broad spectrum of antimicrobial activity (Fedders et al., 2010).

Large scale extractions and supply of the complex natural chemicals from marine bio-resources are environmentally unsound and economically unviable. In this regard, genetic engineering provides a better solution through production of recombinant purified compounds. Purity, safety and effective positive impact on human health care are some of the prevailing advantages of recombinant products against natural extracts, with respect to the pharmaceutical compounds obtained from marine biomasses. Intriguingly, a successful attempt was made by researchers from Australian Institute of Marine Science and London School of Pharmacy, on shotgun cloning and heterologous expression of the patellamide gene cluster, to produce antineoplastic metabolites, patellamides (Long et al., 2005).

Metabolic engineering is a remarkable extension of genetic engineering, which is commonly experienced in terrestrial plants and microorganisms which stands for modification of cellular metabolic pathways to enhance the metabolic composition. Complying with the basic objective, improvement of the metabolic composition can be accomplished through producing new compounds, enhancing the production of existing compounds and eliminating undesirable products of the biosynthetic pathways through introducing novel genes or total pathway and over expression of endogenous pathways. These modifications can be achieved by several possible genetic manipulations, such as up-regulation of transcriptional factors, which in turn enhance the transcription of genes involve in biosynthetic pathway, down regulation of endogenous genes, using anti-sense RNA technology or RNA interference (RNAi) technique to eliminate the obstructive regulation of the synthesis of desired product and increasing the copy number of the gene or genes cluster of interest or driving the expression of the desired genes under strong promoters to over express the genes. In most of the above approaches, transgenic technology is commonly used to introduce the exogenous gene into the desired organism (Tuteja et al., 2012). Among the marine organisms, especially marine microorganisms, algae and sponge like invertebrates can also be considered as prospective candidates to be subjected to the genetic improvements, as described above, to improve them as sustainable resources of bioactive compounds. Eventually, the overall insights into the impact of molecular biology on the field of investigation and development of marine bio-resources convince us a flourishing future, especially with respect to the drug discovery programs.

\section{Future challenges and prospective marine bio- technology}

Marine organism cultivation has been practiced long time ago; however, marine micro and macro algae (seaweeds) are 
much significant and mainly cultivated by two systems such as open culture and closed (photobioreactors) or artificial culture (Fernandez et al., 2013). Particularly, each one of the culturing systems has either desirable or undesirable, since the photosynthetic organisms and their mass production may directly correlate with the source of energy. Open culture systems can be established for seaweed or some of the microalgae farming. and can be achieved by low cost, high capacity and free access solar energy for high photosynthetic efficiencies with long term durability (Robertsonet et al., 2008; Chen et al., 2011). However, impossibility to control temperature, invasion of parasitic algae or other algae strains may result in negative drawbacks. Despite these situations, only selected few microalgae strains can be used in controlled conditions for the cultivation in particular environments like, high alkaline environment for Spirulina splatensis and high salinity condition for Dunaliella salina (Garcia et al., 2003; Harun et al., 2010). However, the production of $\beta$-carotene from $D$. salina is interested in closed culturing system over the open system (Heakal et al., 2010; Prieto et al., 2011). Therefore the closed culture system is preferable for culturing particular microalgae (Sánchez et al., 2008). The controlled optimum condition with the operational inputs such as salt, dissolved $\mathrm{CO}_{2}$, water, nutrients, $\mathrm{pH}$ and $\mathrm{O}_{2}$ provide a great opportunity for the steady environment without being contaminated in the closed cultures. However, a certain type of conditions may lead to the high cost of the closed system than the open system. In fact, these cell factories have gained many opportunistic advantages and still remain a competitive cultivation options for the production of marine algae. In addition, production of marine functional ingredients from marine algae sources is one of the leading industries that correlate with mass culture techniques and uses for the applications in food, pharmaceuticals and cosmetics (Dufosse et al., 2005). For an example, marine pigments, mainly carotenoids including $\beta$-carotene, astaxanthine, lutein, zeaxanthin as well as phycocyanin and chlorophyll have been documented along the production and extraction parameters recently (Gonzalez et al., 2005; Sánchez et al., 2008). In addition, there is a growing awareness on the single cell oils (SCO) due to the richness of PUFA in marine microalgae (Ward and Singh, 2005). Therefore, optimizing photobioreactors for cultures and scaling up approaches have been shown a great deal against different microalgae while opening up a wide market place for them.

Over the many years, there is a new trend behind the cultivation of microorganisms or microorganism associated to invertebrate symbionts by marine scientists. Besides the knowledge of the both open sea-based aquaculture and alternative growing methods are likely to be an important with requiring the detailed information about the biology and life cycle of the culturing organisms and the different symbiotic associations. It is not a surprised fact that the marine organisms and symbiotic associations are important for new functional materials. In fact, the way of applying biotechnology upon the marine eu- karyotes and prokaryotes, along the cultivation is believed as a new research for feeding sources on desired organism and improving the growth rate as well as disease prevention. On the other hand, bioremediation is also an important discipline associated with the marine microorganisms. It is basically degradation of toxic pollutants into non-toxic products through marine microbial community. Marine pollutants including, heavy metals, oil spills, industrial wastes and other nuclear contaminants have become more problematic issues and exerts the bad effects always on marine enviornments. However, marine biotechnology and marine bio-resources can be provided sustainable solutions along the bioremediation (Deng and Wang, 2012). This is an effective and efficient treatment for cleaning up hazardous materials than the conventional methods. Microbial communities and biological remediation will be not damage to the fragile marine ecosystems and described as natural phenomenal approaches. Hence, identification and isolation of specific marine microbes which could accumulate toxic contaminants for bioremediation would be the key successor. In fact, characterizing the culture conditions for surviving in affected areas and for the habitat protection would be expected.

Despite the fact, the aquaculture industry has been developed fast enough to produce more than 16 million tons of fish and shellfish annually for the world food market. FAO (F.A.O., 2010) has noted that the total aquacultural fish production was reported to be increased the range from 15.3 to 21 million tons during the year 2004 to 2009 . Moreover, in terms of the utilization for human consumption, nearly $15.7 \%$ of world population accounted for fish proteins and fish production has been exponentially increased in recent past years. On the other hand, the total marine functional ingredients have been grown faster than the other food ingredients by $8-12 \%$ since 2005. Importantly, marine functional ingredients have attributed in the utilization at pharmaceutical, nutraceutical, health care, food and feed markets. In fact, this market value was reached to approximately 43.5 billion USD in 2010 and showed a 7.3 billion USD growth rate after year 2005 (Elvevoll et al., 2006; Sharma, 2009). Therefore, a wide range of social, economical, institutional and biotechnological considerations are implemented for the development of fish, shellfish and marine microbes cultures. This has been further flourished due to the new vaccine therapies, hormone therapies for gaining resistance and transgenic techniques in advancing on the establishment of aquaculture. However, this would spread more by introducing new species in extensive cultivation, raising the diversity of marine foods or biomedical products and also developing the sustainable practices through the physiological health benefits (Slocombe et al., 2013).

As a consequence, the rapid growth of marine bio-resources and a significant expansion of marine biotechnological aspects are expected within the next few decades, In fact, marine genomics research may involve generating new tools, functional molecular markers, bioinformatics, and new knowledge about 
statistics as well as inheritance phenomena that could increase the efficiency and precision of marine biotechnological applications. In addition, in order to meet the requirements of better understanding with the infrastructures of scientific communities, integrations are needed to fulfill through the collaborative researches. Collectively, capitalizing the knowledge and experience of the marine biotechnologists and strengthening the awareness of interdisciplinary expertise can secure the sustainability of marine bio-resources.

\section{Conflict of Interest}

"The authors declare no conflict of interest".

\section{References}

Alwyn T, Rees V and Victoria JA. 2006. Evidence for an extracellular 1-amino acid oxidase in nitrogen-deprived Phaeodactylum tricornutum (Bacillariophyceae) and inhibition of enzyme activity by dissolved inorganic carbon. Phycologia 45, 337-342.

Andersson M, Benoist B and Rogers L. 2010. Epidemiology of iodine deficiency: salt iodisation and iodine status. Best Pract Res Clin Endocrinol Metab 24, 1-11.

Andreotti G, Giordano A, Tramice A, Mollo E and Trincone A. 2006. Hydrolyses and transglycosylations performed by purified $\alpha$-Dglucosidase of the marine mollusc Aplysia fasciata. J Biotechnol $122,274-284$.

Andrianasolo EH, Haramaty L, Vardi A, White E, Lutz R and Falkowski P. 2008. Apoptosis-inducing galactolipids from a cultured marine diatom, Phaeodactylum tricornutum. J Nat Prod 71, 1197-1201.

Appleton KM, Rogers PJ and Ness AR. 2010. Updated systematic review and meta-analysis of the effects of n-3 long-chain polyunsaturated fatty acids on depressed mood. Am Clin Nutr 91, 757-770.

Baerga-Ortiz A. 2009. Biotechnology and biochemistry of marine natural products. Puerto Rico Health Sci J 28, 251-257.

Bargeman G, Koopsb GH, Houwing J, Breebaartb I, van der Horsta HC and Wesslingb M. 2002. The development of electro-membrane filtration for the isolation of bioactive peptides: the effect of membrane selection and operating parameters on the transport rate. Desalination 149, 369-374.

Bimbo AP. 2007. Current and future sources of raw materials for the long-chain omega-3 fatty acids market. Lipid Technol 19, 176179 .

Bonacci S, Brown MA, Dissanayaka A, Hagger JA, Corsi I, Focardi S and Galloway TS. 2004. Esterase activities in the bivalve mollusc Adamussium colbecki as a biomarker for pollution monitoring in the Antarctic marine environment. Mar Pollut Bull 49, 445-455.

Boukortt FO, Girard A, Prost JL, Ait-Yahia D, Bouchenak M and Belleville J. 2004. Fish protein improves the total antioxidant status of streptozotocin-induced diabetes in spontaneously hypertensive rat. Med Sci Monit 10, 397-404.

Bruno AC, Rossi G, Marcolongo A, Di Lena A and Venzo CP. 2005.
Selective in vivo anti-inflammatory action of the galactolipid monogalactosyldiacylglycerol. Eur J Pharmacol 524, 159-168.

Burtin P. 2003. Nutritional value of seaweeds. EJEAFChe 4, 498-503.

Calzolari IS, Fumagalli N and Marchionni M. 2009. Polyunsaturated fatty acids and cardiovascular disease. Curr Pharm Design 15, 4149-4156.

Cencic A and Chingwaru W. 2010. The role of functional foods, nutraceuticals, and food supplemrnts in intestinal health. Nutrients 2, 611-625.

Ceron MC, Garcia-Malea MC, Rivas J, Acien FG, Fernandez JM, Del Rio E, Guerrero MG and Molina E. 2007. Antioxidant activity of Haematococcus pluviales cells grown in continuous culture as a function of their carotenoid and fatty acid content. Appl Microbiol Biotechnol 74, 1112-1119.

Chabeaud A, Vandanjon L, Bourseau P, Jaouen P, Chaplain-Derouiniot $\mathrm{M}$ and Guerard F. 2009. Performances of ultrafiltration membranes for fractionating a fish protein hydrolysate: application to the refining of bioactive peptic fractions. Sep Purif Technol 66, 463-471.

Chakraborty K and Raj PR. 2007. Eicosapentaenoic acid enrichment from sardine oil by argentation chromatography. J Agr Food Chem $55,7586-7595$.

Chang HW, Jang KH, Lee D, Kang HR, Kim TY, Lee BH, Choi BW, Kim S and Shin J. 2008. Monoglycerides from the brown alga Sargassum sagamianum: Isolation, synthesis, and biological activity. Bioorg Med Chem Lett 18, 3589-3592.

Chen CY, Yeh KL, Aisyah R, Lee DJ and Chang JS. 2011. Cultivation, photobioreactor design and harvesting of microalgae for biodiesel production: A critical review. Bioresource Technol 102, 71-81.

Chiarla C and Giovannini I. 2004. Taurine: Properties and nutritional implication. Riv Ital Nutr Parent Ent 1, 1-7.

Cohen JT, Bellinger DC, Connor WE and Shaywitz BA. 2005. A quantitative analysis of prenatal intake of n-3 polyunsaturated fatty acids and cognitive development. Am J Prev Med 29, 366-374.

Cohen Z, Didi S and Heimer YM. 1992. Overproduction of $\gamma$-linolenic and eicosapentaenoic acids by algae. Plant Physiol 98, 569-572.

Cortes PH, Whitaker JR and Carreno FLG. 1997. Purification and characterization of chymotrypsin from Penaeus vannamei (Crustacea: Decapoda). J Food Biochem 21, 497-514.

Cracraft J and Donoghue MJ. 2005. Assembling the tree of life. Oxford University Press, pp. 592

Dang X and Wang P. 2012. Isolation of marine bacteria highly resistant to mercury and their bioaccumulation process. Bioresoure Technol 121, 342-347.

Debashish G, Malay S, Barindra S and Joydeep M. 2005. Marine enzymes. Adv Biochem Eng Biotechnol 96, 189-218.

Dufosse L, Galaup P, Yaron A, Arad SM, Blanc P, Murthy KNC and Ravishankar GA. 2005. Microorganisms and microalgae as sources of pigments for food use: a scientific oddity or and industrial reality? Trends Food Sci Technol 16, 389-406.

Elias RJ, Kellerby SS and Decker EA. 2008. Antioxidant activity of proteins and peptides. Crit Rev Food Sci 48, 430-441.

Elvevoll E, Barstad H, Breimo E, Brox J, Eilertsen KE and Lund T. 2006. Enhanced incorporation of n-3 fatty acids from fish compared with fish oils. Lipids 41, 1109-1114. 
Elvevoll EO, Eilertsen KE, Brox J, Dragnes BT, Falkenberg P and Olsen JO. 2008. Seafood diets: hypolipidemic and antiatherogenic effects of taurine and n-3 fatty acids. Atherosclerosis 200, 396-402.

Eom TK, Kong CS, Byun HG, Jung WK and Kim SK. 2010. Lipase catalytic synthesis of diacylglycerol from tuna oil and its anti-obesity effect in C57BL/6J mic. Process Biochem 45, 738-743.

Erdmann K, Cheung BWY and Schroder H. 2008. The possible roles of food-derived bioactive peptides in reducing the risk of cardiovascular disease. J Nutr Biochem 19, 643-654.

Fajardo AR, Cerdan LE and Medina AR. 2007. Lipid extraction from the microalga Phaeodactylum tricornutum. Eur J Lipid Sci Technol 109, 120-126.

Farnet CM and Zazopoulos E. 2005. Improving drug discovery from microorganisms. In: Natural Products: Drug Discovery and Therapeutics Medicines. Zhang L, Demain A. eds. Humana Press, New York, US, pp. 95-106.

Fedders H, Podschun R and Leippe M. 2010. The antimicrobial peptide Ci-MAM-A24 is highly active against multidrug-resistant and anaerobic bacteria pathogenic for humans. Int J Antimicrob Agents $36,264-266$.

Feng T, Du Y, Li J, Wei Y and Yao P. 2007. Antioxidant activity of half $\mathrm{N}$-acetylated water soluble chitosan in vitro. Eur Food Res Technol 225, 133-138.

Fernandes P. 2010. Enzymes in Food Processing: A Condensed Overview on Strategies for Better Biocatalysts. Enzyme Res. Advanced online publication.

Fernandez FG, Sevilla JMF and Grima EM. 2013. Photobioreactors for the production of microalgae. Rev Envion Sci Biotechnol 12, 131151.

Ferraro V, Cruz, IB, Jorge RF, Malcata FX, Pintado ME and Castro PML. 2010. Valorisation of natural extracts from marine source focused on marine by-products: A review, Food Res Int 43, 22212233.

Food and Agriculture Organization of the United Nations (FAO). 2010. The State of World Fisheries and Aquaculture.

Friedman M. 1996. Nutritional value of proteins from different food sources: A review. J Agric Food Chem 44, 6-29.

Garcia GM, Moreno J, Canavate JP, Anguis V, Prieto A, Manzano C, Florencio FJ and Guerrero MG. 2003. Conditions for open-air outdor culture of Dunaliella salina in southern Spain. J Appl Phycol $15,177-184$.

Gildberg A. 1983. Purification and characterization of pepsins from the Arctic fish capelin (Mallotus villosus). Comp Biochem Phys B 75, 337-342.

Giordano A, Andreotti G, Mollo E and Tricone A. 2004. Transglycosylation reactions performed by glycosyl hydrolases from the marine anaspidean mollusc Aplysia fasciata. J Mol Cata B: Enzym 30, 51-59.

Gonzalez MG, Moreno J, Manzano JC, Florencio FJ and Guerrero MG. 2005. Production of Dunaliella salina biomass rich in 9-cis$\beta$-Carotene and lutein in a closed tubular photobioreactor. J Biotechnol 115, 81-90.

Gordon A, Hultman E, Kaijser L, Kristjansson S, Rolf CJ and Nyquist O. 1995. Creatine supplementation in chronic heart failure increas- es skeletal muscle creatine phosphate and muscle performance. Cardiovasc Res 30, 413-418.

Gudmundsdottir A and Bjarnason JB. 2008. Applications of cold adapted proteases in the food industry. In: Novel Enzyme Technology for Food Application. Rastall R. ed. Woodhead Publishing Limited, Cambridge, UK, pp. 205-221.

Gust B. 2009. Cloning and analysis of natural product pathways. Methods Enzymol 458, 159-180.

Han X, Budreau AM and Chesney RW. 2000. The taurine transporter gene and its role in renal development. Amino Acids 19, 499-507.

Harnedy PA and Fitzgerald RJ. 2012. Bioactive peptides from marine processing waste and shellfish: A review. J Funct Foods 4, 6-24.

Harun R, Singh M, Forde GM and Dnuah MK. 2010. Bioprocess engineering of microalgae to produce a variety of consumer products. Renew. Sust Energ Rev 14, 1037-1047.

Heakal FEIT, Hefny MM, Tawab AM and Abd El. 2010. Electrochemical behavior of $304 \mathrm{~L}$ stainless steel in high saline and sulphate solutions containing alga Dunaliella salina and $\beta$-Carotene. J Alloy Compd 491, 636-642.

Healy M, Green A and Healy A. 2003. Bioprocessing of marine crustacean shell waste. Acta Biotechnologica 23, 151-160.

Heo SJ, Park EJ, Lee KW and Jeon YJ. 2005. Antioxidant activities of enzymatic extracts from brown seaweeds. Bioresour Technol 96, 1613-1623.

Herrero M, Cifuentes A and Ibanez E. 2006a. Sub- and supercritical fluid extraction of functional ingredients from different natural sources: Plants, food-by-products, algae and microalgae A review. Food Chem 98, 136-148.

Herrero M, Ibanez E, Cifuentes A, Reglero G and Santoyo S. $2006 \mathrm{~b}$. Dunaliella salina microalga pressurized extracts as potencial antimicrobials. J Food Protect 69, 2471-2477.

Heu MS, Kim JS and Shahidi F. 2003. Components and nutritional quality of shrimp processing by-products. Food Chem 82, 235-242.

Holick MF. 2009. Vitamin D status: measurement, interpretation, and clinical application. Ann Epidemiol 19, 73-78.

Hu FB, Bronner L, Willett WC, Stampfer MJ, Rexrode KM and Albert CM. 2002. Fish and omega-3 fatty acid intake and risk of coronary heart disease in women. JAMA 287, 1815-1821.

Imhoff JF, Labes A and Wiese J. 2011. Bio-mining the microbial treasures of the ocean: New natural products. Biotechnol Adv 29, 468482.

Ivanchina NV, Kicha AA and Stonik VA. 2011. Steroid glycosides from marine organisms. Steroids 76, 425-454.

Jacobson TA. 2006. Secondary prevention of coronary artery disease with omega-3 fatty acids. Am J Cardiol 98, 61-70.

Jayasankar V and Subramoniam T. 1997. Proteolytic activity in the seminal plasma of the mud crab, Scylla serrata (Forskål). Comp Biochem Physiol 3, 347-352.

Je JY, Park JY, Jung WK, Park PJ and Kim SK. 2005. Isolation of angiotensin I converting enzyme (ACE) inhibitor from fermented oyster sauce, Crassostrea gigas. Food Chem 90, 809-814.

Je JY, Park PJ, Byun HK, Jung WK and Kim SK. 2005. Angiotensin I converting enzyme (ACE) inhibitory peptide derived from the sauce of fermented blue mussel, Mytilus edulis. Bioresource Tech- 
nol 96, 1624-1629.

Je JY, Qian ZJ, Lee SH, Byun HG and Kim SK. 2008. Purification and antioxidant properties of big eye tuna (Thunnus obesus) dark muscle peptide on free radical-mediated oxidation systems. J Med Food 11, 629-637.

Jimsheena VK and Gowada LR. 2010. Arachin derived peptides as selective angiotensin I-converting enzyme (ACE) inhibitors: Structure-activity relationship. Peptides 31, 1165-1176.

Johansson MW, Keyser P and Soderhall K. 1994. Purification and c DNA cloning of a four-domain kazal proteinase inhibitor from crayfish blood cells. Eur J Biochem 223, 389-394.

Ju SJ and Harvey HR. 2007. Lipids as markers of nutritional condition and diet in the Antarctic krill Euphasia superba and Euphasia crystallorophya during austral winter. Deep-Sea Res Pt II 50, 21992214.

Kanazawa A. 2001. Sterols in marine invertebrates. Fish Sci 67, 9971007.

Karlsen S, Hough E and Olsen RL. 1998. Structure and proposed aminoacid sequence of a pepsin from Atlantic cod (Gadus morhua). Acta Cryst 54, 32-46.

Kawasaki T, Seki E, Osajima K, Yoshida M, Asada K and Matsui T. 2000. Antihypertensive effect of valyl-tyrosine, a short chain peptide derived from sardine muscle hydrolyzate, on mild hypertensive subjects. J Hum Hypertens 14, 519-523.

Khandeparker R, Verma P and Deobagkar D. 2011. A novel halotolerant xylanase from marine isolate Bacillus subtilis cho40: gene cloning and sequencing. New Biotechnol 28, 814-821.

Kim SK and Mendis E. 2006. Bioactive compounds from marine processing byproducts - A review. Food Res Int 39, 383-393.

Kim SK and Wijesekara I. 2010. Development and biological activities of marine-derived bioactive peptides: A review. J Funct Foods 2, 1-9.

Kim SK, Choi YR, Park PJ, Choi JH and Moon SH. 2000. Screening of biofunctional peptides from cod processing wastes. J Korean Soc Agr Chem Biotechnol 33, 198-204.

Kim SK, Kim YT, Byun HG, Nam KS, Joo DS and Shahidi F. 2001. Isolation and characterization of antioxidative peptides from gelatin hydrolysate of Alaska pollack skin. J Agr Food Chem 49, 19841989.

Kitts DD and Weiler K. 2003. Bioactive proteins and peptides from food sources. Applications of bioprocesses used in isolation and recovery. Curr Pharm Des 9, 1309-1323.

Ko SC, Kang MC, Lee JK, Byun, HG, Kim SK and Lee SC. 2011. Effect of angiotensin I-converting enzyme (ACE) inhibitory peptide purified from enzymatic hydrolysates of Styela plicata. Eur Food Res Technol 233, 915-922.

Ko SC, Kim DG, Han CH, Lee YJ, Lee JK and Byun HG. 2012. Nitric oxide-mediated vasorelaxation effects of anti-angioatensin Iconverting enzyme (ACE) peptide from Styela clava flesh tissue and its anti-hypertensive effect on spontaneously hypertensive rats. Food Chem 134, 1141-45.

Kuusksalu A, Pihlak A, Muller WEG and Kelve M. 1995. Identification of the reaction products of oligoadenylate synthetase in the marine sponge. Eur J Biochem 232, 351-357.
Larsen RL, Asgeirsson B, Thorolfsson M, Madsen MN and Hojrup P. 1996. Structure of chymotrypsin variant B from Atlantic cod, $\mathrm{Ga}$ dus morhua. BBA-Protein Struct M 13, 49-56.

Lavie CJ, Milani RV, Mehra MR and Ventura HO. 2009. Omega-3 polyunsaturated fatty acids and cardiovascular diseases. J Am Coll Cardiol 54, 585-594.

Lavigne C, Tremblay F, Asselin G, Jacques H and Marette A. 2001. Prevention of skeletal muscle insulin resistance by dietary cod protein in high fat-fed rats. Am J Physiol Endocrinol Metab 281, 62-71.

Lee JK, Jeon JK and Byun HG. 2011. Effect of angiotensin I converting enzyme inhibitory peptide purified from skate skin hydrolysate. Food Chem 125, 495-499.

Li A and Piel J. 2002. A gene cluster from a marine Streptomyces encoding the biosynthesis of the aromatic spiroketal polyketide griseorhodin A. Chem Biol 9, 1017-1026.

Lichtenstein AH, Appel LJ, Brands M, Carnethon M, Daniels S and Franch HA. 2006. Diet and Lifestyle Recommendations Revision 2006: a scientific statement from the American Heart Association Nutrition Committee. Circulation 114, 82-96.

Long PF, Dunlap WC, Battershill CN and Jaspars M. 2005. Shotgun cloning and heterologous expression of the patellamide gene cluster as a strategy to achieving sustained metabolite production. Chem Bio Chem 6, 1760-1765.

Mahajan PM, Nayak S and Lele SS. 2011. Fibrinolytic enzyme from newly isolated marine bacterium Bacillus subtilis ICTF-1: Media optimization, purification and characterization. J Biosci Bioeng 113, 307-314.

Marchioli R. 2003. Omega-3 polyunsaturated fatty acids and cardiovascular diseases. Minerva Cardioangiol 5, 561-576.

Marik PE and Varon J. 2009. Omega-3 dietary supplements and the risk of cardiovascular events: a systematic review. Clin Cardiol 32, 365-372.

Martinez A, Hopke J, MacNeil IA and Osburne MS. 2005. Accessing the genomes of uncultivated microbes for novel natural products. In: Natural Products: Drug Discovery and Therapeutics Medicines. Zhang L, Demain A. eds. Humana Press, New York, US, pp. 295314.

Matsubara K, Hori K, Matsuura Y and Miyazawa K. 2000. Purification and characterization of a fibrinolytic enzyme and identification of fibrinogen clotting enzyme in a marine green alga, Codium divaricatum. Comp Biochem Phys B 125, 137-143.

Mendes RL, Fernandes HL, Coelho JP, Reis EC, Cabral JMS, Novais JM and Palabra AF. 1995. Supercritical $\mathrm{CO}_{2}$ extraction of carotenoids and other lipids from Chlorella vulgaris. Food Chem 53, 99-103.

Mendiola JA, Jaime L, Santoyo S, Reglero G, Cifuentes A, Ibanez E and Senorans FJ. 2007. Screening of functional compounds in supercritical fluid extracts from Spirulina platensis. Food Chem 102, 1357-1367.

Métayer S, Seiliez I, Collin A, Duchêne S, Mercier Y and Geraert PA. 2008. Mechanisms through which sulfur amino acids control protein metabolism and oxidative status. J Nutr Biochem 19, 207-215.

Miyanishi N, Hamada N, Kobayashi T, Imada C and Watanabe E. 2003. Purification and Characterization of a Novel Extracellular $\beta-1,3$ 
-Glucanase Produced by Bacillus clausii NM- 1 Isolated from Ezo abalone Haliotis discus hannai. J Biosci Bioeng 95, 45-51.

Mogedas B, Casal C, Forjan E and Vilchez C. 2009. $\beta$-Carotene production enhancement by UV-A radiation in Dunaliella bardawil cultivated in laboratory reactors. J Biosci Bioeng 108, 47-51.

Mondello L, Tranchida PQ, Dugo P and Dugo G. 2006. Rapid, microscale preparation and very fast gas chromatographic separation of cod liver oil fatty acid methyl esters. J Pharmaceut Biomed 41, 1566-1570.

Moyano FJ, Diaz FJ and Alarcon SMC. 1996. Characterization of digestive enzyme activity during larval development of gilthead seabream (Sparus aurata). Fish Physiol Biochem 15, 121-130.

Mozaffarian and D, Rimm EB. 2006. Fish intake, contaminants, and human health evaluating the risks and the benefits. JAMA 296, 1885-1899.

Müller WEG, Muller I and Zahn RK. 1974. Protein synthesis of the sponge Geodia cydonium: Charachterization of the system. Nucleic Acids Res 6, 835-847.

Ngo DN, Qian ZJ, Je JY, Kim MM and Kim SK. 2008. Aminoethyl chitooligosaccharides inhibit the activity of angiotensin converting enzyme. Process Biochem 43, 119-123.

Nozawa H, Mamegoshi SC and Seki N. 1997. Partial purification and characterization of six transglutaminases from ordinary muscles of various fishes and marine invertebrates. Comp Biochem Physiol 2, 313-317.

Patel VJ, Lee KW, Tomson J, Dubb K, Huges, EA and Lip GYH. 2007. Effects of omega-3 polyunsaturated fatty acids on metabolically active hormones in patient post-myocardial infarction. Int J Cardiol $115,42-45$.

Patil GS, Chethana MC, Madhusudhan KSMS and Raghavarao. 2008. Fractionation and purification of the phycobiliproteins from Spirulina platensis. Bioresource Technol 99, 7393-7396.

Patrzykat A and Douglas SE. 2003. Gone gene fishing: how to catch novel marine antimicrobials. Trends Biotechnol 21, 362-369.

Petrosian AM and Haroutounian JE. 2009. Taurine as a universal carries of lipid soluble vitamins: A hypothesis. Amino Acids 19, 409-421.

Pihlanto-Leppala A. 2001. Bioactive peptides derived from bovine proteins: Opioid and ACE-inhibitory peptides. Trends Food Sci Technol 11, 347-356.

Plaza M, Cifuentes A and Ibánez E. 2008. In the search of new functional food ingredients from algae. Trends Food Sci Technol 19, 31-39.

Plaza M, Herrero M, Cifuentes A and Ibanez E. 2009. Innovative natural functional ingredients from microalgae. J Agr Food Chem 57, 7159-7170.

Prieto A, Canavate JP and Gonzalez MG. 2011. Assessment of carotenoid production by Dunaliella salina in different culture systems and operation regimes. J Biotachnol 151, 180-185.

Rasmssen B, Fletcher IR, Brocks JJ and Kilburn MR. 2008. Reassessing the first appearance of eukaryotes and cyanobacteria. Nature 255, 1101-1104.

Redmond HP, Stapleton PP, Neary P and Bouchier-Hayes D. 1998. Immunonutrition: The role of taurine. Nutrition 14, 599-604.

Reintamm T, Lopp A, Kuusksalu A, Pehk T and Kelve M. 2003. ATP $\mathrm{N}$-glycosidase - a novel ATP-converting activity from a marine sponge Axinella polypoides. Eur J Biochem 270, 4122-4132.

Riediger ND, Othman RA, Suh M and Moghadasian MH. 2009. A systemic review of the roles of $n-3$ fatty acids in health and disease. $J$ Am Diet Assoc 109, 668-679.

Robertson ADV, Potgieter M, Hansen J, Bolton JJ, Troell M and Anderson RJ. 2008. Integrated seaweed cultivation on an abalone farm in South Africa. J Appl Phycol 20, 579-595.

Rodriguez AR, Reglero G and Ibanez E. 2010. Recent trends in the advanced analysis of bioactive fatty acids. J Pharmaceut Biomed 51, 305-326.

Rolland JL, Abdelouahab M, Dupont J, Lefevre F, Bachere E and Romestand B. 2010. Stylicins, a new family of antimicrobial peptides from the Pacific blue shrimp Litopenaeus stylirostris. Mol Immunol 47, 1269-1277.

Rose SJ. 1996. Taurine in neonatal nutrition. Semin Neonatol 1, 35-41. Rosell M, Wesley AM, Rydin K, Klareskog L and Alfredsson L. 2009. Dietary fish and fish oil and the risk of rheumatoid arthritis. Epidemiology 20, 896-901.

Rutherfurd MKJ and Moughan PJ. 2005. Bioactive peptides derived from food. AOAC Int 88, 955-966.

Saborowski R and Buchholz F. 2002. Metabolic properties of Northern krill, Meganyctiphanes norvegica, from different climatic zones: Enzyme characteristics and activities. Mar Biol 140, 557-565.

Saha KS, Swaminathan P, Raghavan C, Uma L and Subramanian G. 2010. Ligninolytic and antioxidative enzymes of a marine cyanobacterium Oscillatoria willei BDU 130511 during Poly R - 478 decolourization. Bioresource Technol 101, 3076-3084.

Samarakoon K and Jeon YJ. 2012. Bio-functionalities of proteins derived from marine algae-A review. Food Res Int 48, 948-960.

Samaranayaka AGP and Li-Chan ECY. 2011. Food-derived peptidic antioxidants: A review of their production, assessment, and potential applications. J Funct Foods 3, 229-254.

Sánchez JF, Fernández JM, Acién FG, Rueda A, Pérez-Parra J and Molina E. 2008. Influence of culture conditions on the productivity and lutein content of the new strain Scenedesmus almeriensis. Process Biochem 43, 398-405.

Saremi A and Arora R. 2009. The utility of omega-3 fatty acids in cardiovascular disease. Am J Ther 16, 421-436.

Schuchardt JP, Huss M, Stauss-Grabo M and Hahn A. 2010. Significance of long-chain polyunsaturated fatty acids (PUFAs) for the development and behavior of children. Eur J Pediatrics 169, 149164.

Senni K, Pereira J, Gueniche F, Ladrat CD, Sinquin C and Ratiskol J. 2011. Marine Polysaccharides: A source of bioactive molecules for cell therapy and tissue engineering. Mar Drugs 9, 1664-1681.

Shahidi F and JanakKamil YVA. 2001. Enzymes from fish and aquatic invertebrates and their application in the food industry, Review. Trends Food Sci Technol 12, 435-464.

Shahidi F and Wanasundara UN. 1998. Omega-3 fatty acid concentrates: Nutritional aspects and production technologies. Trends Food Sci Tech 9, 230-240.

Shahidi F and Zhong Y. 2008. Bioactive peptides. J AOAC Int 91, 914931.

Sharma R. 2009. Market intelligence and innovations in functional 
foods and nutraceuticals. Function Foods Weekly 3, 1-21.

Shashikant CS and Ruddle FH. 2003. Impact of transgenic technologies on functional genomics. Curr Issues Mol Biol 5, 75-98.

Sheih IC, Wu TK and Fang TJ. 2009. Antioxidant properties of a new antioxidative peptide from algae protein hydrolysate in different oxidation systems. Bioresource Technol 100, 3419-3425.

Slocombe SP, Zhang QY, Black KD, Day JG and Stanly MS. 2013. Comparison of screening methods for high-throughput determination of oil yields in micro-algal biofuels strains. J Appl Phycol 25, 961-972.

Sperstad SV, Haug T, Blencke HM, Styrvold OB, Li C and Stensvag K. 2011. Antimicrobial peptides from marine invertebrates: Challenges and perspectives in marine antimicrobial peptide discovery. Biotechnol Adv 29, 519-530.

Stapleton PP, Charlses RP, Redmond HP and Bouchier-Hayes DJ. 1997. Taurine and human nutrition Clin Nutr 16, 103-108.

Stengel DB, Connan S and Popper ZA. 2011. Algal chemodiversity and bioactivity: Sources of natural variability and implications for commercial applications. Biotechnol Adv 29, 483-501.

Streit WR and Schmitz RA. 2004. Metagenomics the key to the uncultured microbes. Curr Opin Microbiol 7, 492-498.

Sudek S, Lopanik NB, Waggoner LE, Hildebrand M, Anderson C, Liu H, Patel A, Sherman DH and Haygood MG. 2007. Identification of the putative bryostatin polyketide synthase gene cluster from "Candidatus Endobugula sertula", the uncultivated microbial symbiont of the marine bryozoan Bugula neritina. J Nat Prod 70, 67-74.

Suetsuna K and Chen JR. 2001. Identification of antihypertensive peptides from peptic digests of two microalgae, Chlorella vulgaris and Spirulina platensis. Mar Biotechnol 3, 305-309.

Sullivan PG, Geiger JD, Mattson MP and Scheff SW. 2000. Dietary supplement creatine protects against traumatic brain injury. Ann Neurol 48, $723-729$.

Szymanski KM, Wheeler DC and Mucci LA. 2010. Fish consumption and prostate cancer risk: a review and meta-analysis. Am J Clin Nutr 92, 1223-1233.

Takahashi K, Schaffer SW and Azuma J. 1997. Taurine prevents intracellular calcium overload during calcium paradoxe of cultured cardiomyocytes. Amino Acids 13, 1-11.

Taylor AG and Savage C. 2006. Fatty acid composition of New Zealand green-lipped mussels, Perna canaliculus: Implications for harvesting for n-3 extracts. Aquaculture 261, 430-439.

Teta R, Gurgui M, Helfrich EJ, Kunne S, Schneider A and Van EchtenDeckert G. 2010. Genome mining reveals trans-AT polyketide synthase directed antibiotic biosynthesis in the bacterial phylum bacteroidetes. Chem Bio Chem 11, 2506-2512.

Thakur NL, Jain R, Natalio F, Hamer B, Thakur AN and Muller WE. 2008. Marine molecular biology: an emerging field of biological sciences. Biotechnol Adv 26, 233-245.

Tuteja N, Verma S, Sahoo RK, Raveendar S and Reddy IN. 2012. Recent advances in development of marker-free transgenic plants: regulation and biosafety concern. J Bioscience 37, 167-97.

Ueno Y, Kurano N and Miyachi S. 1999. Purification and characterization of hydrogenase from the marine green alga, Chlorococcum littorale. FEBS letters 443, 144-148.

Undeland I, Lindqvist H, Chen-Yun Y, Falch E, Ramel A and Cooper M. 2009. Seafood and health — what is the full story? In: Marine functional food. Luten JB. Ed. Wageningen Academic Publishers, Wageningen, Neth, pp. 17-87.

Wang HM, Pan JL, Chen CY, Chiu CC, Yang MH and Chang HW. 2010. Identification of anti-lung cancer extract from Chlorella vulgaris C-C by antioxidant property using supercritical carbon dioxide extraction. Process Biochem 45, 1865-1872.

Ward OP and Singh A. 2005. Omega-3/6 fatty acids: Alternative source of production. Process Biochem 40, 3627-3652.

Williams PJB and Laurens LML. 2010. Microalgae as biodiesel \& biomass feedstocks: Review \& analysis of the biochemistry, energetic \& economics. Energ Environ Sci 3, 554-590.

Woyke T, Xie G, Copeland A, Gonzalez JM, Han C and Kiss H. 2009. Assembling the marine metageonome, one cell at a time. PLoS One 4, e5299.

Wu T, Fu J, Yang Y, Zhang L and Han J. 2009. The effects of phytosterols/stanols on blood lipid profiles: a systematic review with metaanalysis. Asia Pac J Clin Nutr 18, 179-186.

Xu RA, Wong RJ, Rogers ML and Fletcher GC. 1996. Purification and characterization of acidic proteases from the stomach of the deepwater finfish orange roughy (Hoplostethus atlanticus). J Food Biochem 20, 31-48.

Xue C, Hu Y, Saito H, Zhang Z, Li Z and Cai Y. 2002. Molecular species composition of glycolipids from Sprirulina platensis. Food Chem 77, 9-13.

Yaqin K and Hansen PD. 2010. The use of cholinergic biomarker, cholinesterase activity of blue mussel Mytilus edulis to detect the effects of organophosphorous pesticides. Afr J Biochem Res 12, 265-272.

Zazopoulos E, Huang K, Staffa A, Liu W, Bachmann BO and Nonaka K. 2003. A genomics-guided approach for discovering and expressing cryptic metabolic pathways. Nat Biotechnol 21, 187-90.

Zengler K, Paradkar A and Keller M. 2005. New methods to access microbial diversity for small molecule discovery. In: Natural Products: Drug Discovery and Therapeutics Medicines. Zhang L, Demain A. eds. Humana Press, New York, US, pp. 275-294.

Zhu Y and Jiang J. 2008. Continuous cultivation of Dunaliella salina in photobioreactor for the production of $\beta$-carotene. Eur Food Res Technol 227, 953-959.

Zimmermann MB. 2010. Symposium on 'geographical and geological influences on nutrition': Iodine deficiency in industrialized countries. Proc Nutr Soc 69, 133-143.

Zuliani G, Galvani M, Leitersdorf E, Volpato S, Cavelieri M and Fellin R. 2009. The role of polyunsaturated fatty acids (PUFA) in the treatment of dyslipidemias. Curr Pharma Design 15, 4173-4185. 